\title{
Urinary Albumin Excretion in Normal Subjects and in Diabetic Patients Measured by a Radioimmunoassay: Methodological and Clinical Aspects
}

\author{
OTTAVIO GIAMPIETRO, ROBERTO MICCOLI, ALDO CLERICO, LUIGI DI PALMA, \\ ALESSANDRA BERTOLOTTO, ROBERTO ANICHINI, RENZA CRISTOFANI, \\ and RENZO NAVALESI
}

\author{
Cattedra di Malattie del Ricambio, Istituto di Clinica Medica II, C.N.R. Clinical Physiology Institute, \\ Universita' di Pisa, Italy
}

\begin{abstract}
We have developed a radioimmunoassay method $(R \mid A)$ to measure urinary albumin excretion. We determined the albumin excretion rate (AER) ( $\mu \mathrm{g} / \mathrm{min}$ ) of 122 healthy subjects and 145 diabetic patients ( 115 type I, 30 type II). The results indicate that the RIA is sensitive $(0.39 \pm 0.08 \mathrm{mg} / \mathrm{L})$, precise (CV 5-8\%), and gives reliable results on previously frozen urine samples. The distribution of the AER values in healthy subjects and diabetic patients was not normal. It was normalized by log or square-root transformation of the data. Seventythree percent of diabetic patients lay within the normal range $(0.6-$ $10.6 \mu \mathrm{g} / \mathrm{min}$ ). Twenty percent could be considered "at risk" to develop overt diabetic nephropathy because their albuminuria exceeded a threshold level of $15 \mu \mathrm{g} /$ min chosen previously as the cutoff value for microalbuminuria.

We found no correlation between AER and glycated hemoglobin, and only a weak correlation between AER and diabetes duration in type I diabetic patients.
\end{abstract}

KEY WORDS: urinary albumin; microalbuminuria; AER; diabetic nephropathy; diabetes mellitus; radioimmunoassay.

M croalbuminuria is defined as an increased urinary albumin excretion rate (AER) that is above the upper normal limit, but not detectable by standard clinical tests such as Albustix (Miles GmbH, Sparte Ames, Frankfurt, West Germany) (1-2).

The clinical relevance and usefulness of the measurement of microalbuminuria as a predictor of overt diabetic nephropathy has been assessed by long-term prospective studies performed both in type I, insulindependent (3-5) and in type II, maturity-onset diabetic subjects (6). These studies have shown that microalbuminuria is strongly prognostic of persistent, Albustix-positive proteinuria, the hallmark and starting point of clinical diabetic nephropathy (3-6). In addition, microalbuminuria, both in type I and in type II diabetic patients, has been shown to predict increased mortality not only of renal origin, but also from cardiovascular disease $(6,7)$.

Correspondence: Ottavio Giampietro, MD, Cattedra di Malattie del Ricambio, Istituto di Clinica Medica II, Via Roma, 67,56100 PISA, Italy.

Manuscript received May 10, 1987; accepted August 12, 1987.

*In our laboratory, the normal range of $\mathrm{HbAlc}$ is 4 to $6 \%$.
Several methods, among which radial immunodiffusion (8) and radioimmunoassay $(9-12)$ have been the most widely used, can measure small concentrations of albumin in urine. Until now however, they have been limited to a few research laboratories (12). With the availability of new commercial kits for the RIA assessment of albuminuria, more extensive studies on the utility of microalbuminuria as a marker of clinical nephropathy is possible. Issues to be resolved are the distribution of AER values in normal and diabetic subjects (13), the development of normal ranges, the day-to-day variability of urinary albumin excretion (14), and the mode of collection and storage of urine samples. In this article, we describe the characteristics of the RIA method developed in our laboratory and report results that address these issues.

\section{Materials and methods}

\section{SUBJECTS}

Urinary albumin excretion was measured in 122 healthy subjects (58 males and 64 females; age, 16-59 years; $m \pm S D, 29.6 \pm 8.5$ ) in 115 type I, insulin-dependent diabetic patients (51 males and 64 females; age, 9-66 years; $31.1 \pm 14$; duration of diabetes: $1-37$ years, $11.2 \pm 7.5$; fasting plasma glucose: $4.4-7.7 \mathrm{mmol} /$ L; glycated hemoglobin, HbA1c: $4.5-11 \%, 7.6 \pm 1.3)^{*}$, and in 30 type $\Pi$, maturity-onset diabetic patients $(16$ males and 14 females; age, 25-72 years, $50.4 \pm 11.1$; diabetes duration: $1-39$ years, $9.9 \pm 8$; fasting plasma glucose: $5-7.7 \mathrm{mmol} / \mathrm{L}$; HbAlc: $5-10 \%, 7.6 \pm 1.5$ ). All the subjects studied were within $10 \%$ of ideal body weight, had no history of renal or urinary tract disease, and had negative urine cultures. They were Albustixnegative, normotensive, and with normal renal function (creatinine clearance in normals, type I and II diabetics was $2.02 \pm 0.6 \times 10^{-3} ; 1.98 \pm 0.41 \times 10^{-3} ; 1.95$ $\pm 0.41 \times 10^{-3} \mathrm{~L} / \mathrm{s}$, respectively). Timed, overnight urine collections were used (3). Every subject collected urine for at least three consecutive nights. Albumin was measured on each of these specimens, and the mean 
value was expressed as AER in $\mu \mathrm{g} / \mathrm{min}$. All urines were collected in plastic tubes with no additive or preservative and stored at $-20^{\circ} \mathrm{C}$ until assayed.

\section{RIA SYSTEM}

The standard for the RIA is purified human serum albumin (HSA) (HSA, crystallized and lyophilized, essentially globulin-free; Sigma, St. Louis, MO 63178). 125-I-HSA is the tracer and a specific anti-HSA serum, (Sclavo S.p.A., Cinisello Balsamo, Italy) is the antibody. The separation of the bound from the free phase is by second antibody (goat anti-rabbit-gamma globulins diluted 1:100 in the Tris-EDTA buffer) plus PEG (8\% polyethylene glycol in Tris $0.05 \mathrm{M}$, pH 8.6 buffer).

The standard curve is prepared by diluting a solution (100 mg/L) of purified HSA with Tris-EDTA buffer (Tris buffer $0.1 \mathrm{M}, \mathrm{pH} 8.6$, with EDTA $0.02 \mathrm{M}$, sodium azide $1 \mathrm{~g} / \mathrm{L}$, and gelatin $2 \mathrm{~g} / \mathrm{L}$ ) to give seven standards, containing $3,5,10,15,20,30$, and $50 \mathrm{mg} / \mathrm{L}$ of HSA, respectively (Figure 1); $25 \mu \mathrm{L}$ of each is used in the assay.

The 125-I-HSA is prepared by the Chloroamine-Tmethod (15). The specific activity obtained after chromatographic purification on Sephadex G75 column was 30 to $40 \mu \mathrm{Ci} / \mu \mathrm{g}$. A solution containing 3 to $4 \times 10^{4}$ $\mathrm{cpm}$ in $100 \mu \mathrm{L}$ (about $10 \mu \mathrm{g} / \mathrm{L}$ of 125-I-USA in the TrisEDTA buffer) is used in the assay. The antiserum was raised in rabbits and diluted 1:1000 with the Tris-EDTA buffer. The bovine serum albumin (BSA for RIA assay, Miles Laboratories, Inc., Naperville, IL 60566) shows no crossreactivity $\left(\mathrm{B} / \mathrm{B}_{0}<5 \%\right)$ up to a concentration of $100 \mathrm{~g} / \mathrm{L}$. There is negligible crossreactivity also with human gamma globulin $(0.3 \%)$ and human transferrin $(<0.01 \%)$.

The assay is performed as follows: $25 \mu \mathrm{L}$ of the standard solution or undiluted urine sample, $100 \mu \mathrm{L}$ of the antiserum and $100 \mu \mathrm{L}$ of the second antibody are added to each tube. After mixing, the tubes are incubated (1 h) at room temperature $\left(18-22^{\circ} \mathrm{C}\right)$. Two $\mathrm{mL}$ of $\mathrm{PEG}$ solution are added to each tube and after centrifugation $\left(1500 \times \mathrm{g}\right.$ for $10 \mathrm{~min}$ at $\left.4^{\circ} \mathrm{C}\right)$, the supernates are removed by aspiration and the precipitates counted in a well-type gamma counter. All sample values, the index of sensitivity, the precision profile, and the quality control of the assay are calculated using a previously described data validation program (16). An AER cutoff value of $15 \mu \mathrm{g} / \mathrm{min}$ was chosen for diagnosis of $\mathrm{mi}$ croalbuminuria $(5,6)$. Statistical analysis of the patients, data was performed using a standard statistical package (17) on an IBM 370.

\section{Results}

\section{RIA SYSTEM}

Figure 1 shows the mean standard curve ( \pm SD), the mean precision profile, the mean degree of sensitivity, the mean binding capacity $\left(\mathrm{B}_{0} / \mathrm{T}\right)$, and the mean percent nonspecific counts (N/T) of our RIA system, obtained from 40 different assays performed over 18 months. The degree of precision and sensitivity permits the measurement of AER even in normal subjects. However, when necessary, 50 or $100 \mu \mathrm{L}$ of urine samples, instead of $25 \mu \mathrm{L}$, may be assayed.

A linear response $(r>0.98)$ was obtained when increasing volumes of eight different urinary samples containing albumin concentrations from 20 to $130 \mathrm{mg} /$ $\mathrm{L}$ were assayed. Urine samples containing very high albumin concentrations may be diluted for the assay. Quantitative recovery was obtained when known amounts of purified HSA were added to three different urine samples (two assayed after storage at $-20^{\circ} \mathrm{C}$ and
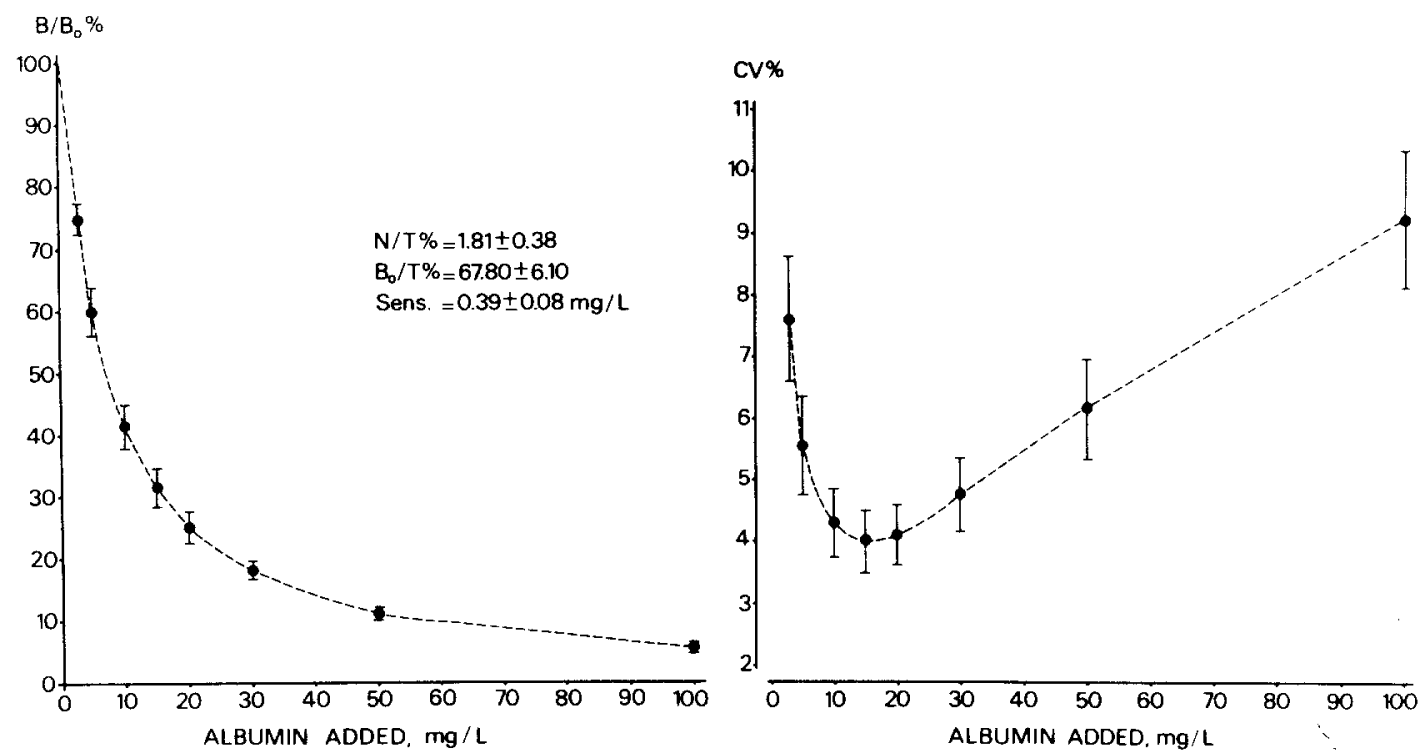

Figure 1-Mean $( \pm \mathrm{SD})$ standard curve, mean precision profile, mean degree of sensitivity, mean binding capacity $\left(\mathrm{B}_{0} / \mathrm{T}\right)$ and mean aspecific counts (N/T) of our RIA method obtained in different 40 experiments during 18 month-period. 
TABLE 1

Stability of Urinary Albumin Value $(\mu \mathrm{g} / \mathrm{ml})$ in Multiple Thawing and Freezing Experiments Performed During a Three Week Period

\begin{tabular}{crrccc}
\hline Sample & Fresh & $\begin{array}{c}\text { 4 days } \\
\text { (first thawing) }\end{array}$ & $\begin{array}{c}\text { 8 days } \\
\text { (second thawing) }\end{array}$ & $\begin{array}{c}15 \text { days } \\
\text { (third thawing) }\end{array}$ & $\begin{array}{c}21 \text { days } \\
\text { (fourth thawing) }\end{array}$ \\
\hline 1 & 2.30 & 2.16 & 1.97 & 2.47 & 2.21 \\
2 & 11.40 & 8.80 & 8.33 & 9.75 & 9.37 \\
3 & 27.60 & 25.70 & 26.16 & 25.79 & 26.68 \\
4 & 12.80 & 13.03 & 12.93 & 12.41 & 13.19 \\
5 & 7.94 & 7.46 & 6.83 & 7.45 & 7.90 \\
6 & 1.97 & 2.10 & 1.58 & 2.17 & 1.76 \\
7 & 6.25 & 5.67 & 5.30 & 5.29 & 5.34 \\
8 & 40.70 & 37.57 & 34.05 & 38.39 & 40.29 \\
9 & 6.80 & 6.70 & 6.26 & 6.24 & 6.00 \\
10 & 45.62 & 47.19 & 50.32 & 47.50 & 48.45 \\
& & & & & \\
Mean & 16.34 & 15.64 & 15.37 & 15.75 & 16.12 \\
SD & 15.92 & 15.78 & 16.22 & 15.97 & 16.6 \\
\hline
\end{tabular}

NOTE: Each urine sample has been measured first at fresh, and then after four repeated freezing and thawing experiments.

one without freezing), mean percent recovery ranging from 98 to $103 \%$.

The between-batch precision was assessed by assaying three urine pools over several months (16 months: pool $\mathrm{A}$ and $\mathrm{B}$; 8 months: pool $\mathrm{C}$ ). The method shows good precision (CV ranging between 5-8\%). Significant degradation of immunoreactive endogenous HSA was not observed in stored urine samples during the study.

We found no reduction of measured albumin in several $(n=4)$ freezing and thawing experiments performed in 10 urines over three weeks (Table 1), and no significant differences were found between eight urine samples assayed before (mean $11.1 \pm 6.7 \mathrm{mg} / \mathrm{L}$ ) and after centrifugation (mean $11.3 \pm 6.5 \mathrm{mg} / \mathrm{L}$ ).

\section{Clinical results}

The distribution of AER values in the 122 normal subjects is not Gaussian (Figure 2A) $(p<0.013$, test di Somers) (18), and the log transformation of data did not normalize the curve ( $p<0.01$, Figure 2B). A normal distribution was achieved after the square-root transformation of AER values (Figure 2C).

The range of AER in healthy control subjects was 0.6 to $10.6 \mu \mathrm{g} / \mathrm{min}$ (1st-99th percentile) with a mean value of $4.42 \pm 1.99 \mu \mathrm{g} / \mathrm{min}$ (median 4.27) (Table 2).

In diabetic patients, the mean AER was $12 \mu \mathrm{g} / \mathrm{min}$, (range 1-110) and about 70\% were within normal limits (Figure 3). The mean AER of both type I $(12.5 \mu \mathrm{g} / \mathrm{min}$, range $1.3-110)$ and type $I I(10 \mu \mathrm{g} / \mathrm{min}$, range $1-39)$ diabetic patients was significantly higher than the AER of normal subjects $(p<0.001)$.

In 92 normoalbuminuric type I diabetic patients, the AER was $6.3 \pm 2.8 \mu \mathrm{g} / \mathrm{min}$ (range $1.3-13.6$ ). In the 24 normoalbuminuric type II diabetics, the AER was $5.2 \pm 3.3 \mu \mathrm{g} / \mathrm{min}$ (range 1-14). The AER of normoalbuminuric type I and type II diabetic patients was significantly higher than that of the controls, $(p<$ 0.01 , one-way ANOVA), but the data from the two groups of diabetics did not differ (Table 2).

TABLE 2

Clinical and Metabolic Characteristics of Subjects Studied

\begin{tabular}{|c|c|c|c|c|c|}
\hline & & \multicolumn{2}{|c|}{$\begin{array}{l}\text { Control Subjects } \\
(n=122)\end{array}$} & \multicolumn{2}{|c|}{$\begin{array}{l}\text { Diabetic Patients } \\
\qquad(n=145)\end{array}$} \\
\hline & & \multicolumn{2}{|c|}{ Type I } & \multicolumn{2}{|c|}{ Type II } \\
\hline & & $\begin{array}{l}\text { Normo- } \\
\text { albuminuria } \\
(<15 \mu \mathrm{g} / \mathrm{min}) \\
(n=92)\end{array}$ & $\begin{array}{c}\text { Micro- } \\
\text { albuminuria } \\
(>15 \mu \mathrm{g} / \mathrm{min}) \\
(n=23)\end{array}$ & $\begin{array}{c}\text { Normo- } \\
\text { albuminuria } \\
(<15 \mu \mathrm{g} / \mathrm{min}) \\
(n=24)\end{array}$ & $\begin{array}{c}\text { Micro- } \\
\text { albuminuria } \\
(>15 \mu \mathrm{g} / \mathrm{min}) \\
(n=6)\end{array}$ \\
\hline $\operatorname{Sex}(M: F)$ & $58 / 64$ & $42 / 50$ & $9 / 14$ & $12 / 12$ & $4 / 2$ \\
\hline Age (years) & $29.6(16-59)$ & $29(9-66)$ & $39(16-65)$ & $50(27-72)$ & $51(25-63)$ \\
\hline Duration of diabetes & - & $10(1-28)$ & $15(2-37)$ & $9(1-39)$ & $12(1-22)$ \\
\hline $\begin{array}{l}\text { Albumin Excretion } \\
\text { Rate (AER) }(\mu \mathrm{g} / \mathrm{min})\end{array}$ & $4.42(0.6-10.6)$ & $6.3(1.3-13.6)^{\mathrm{a}}$ & $36.9(15-110)$ & $5.2(1-14)^{\mathrm{a}}$ & $26(18-39)$ \\
\hline $\begin{array}{l}\text { Creatinine Clearance } \\
(\mathrm{L} / \mathrm{s})\end{array}$ & $2.02(1.20-3.31)^{\mathrm{b}}$ & $1.93(0.86-3.28)^{b}$ & $2.16(1.48-3.28)^{b}$ & $1.83(1.46-2.16)^{\mathrm{b}}$ & $2.08(1.28-2.93)^{\mathrm{b}}$ \\
\hline HbAlc $(\%)$ & $5.2(4.5-5.9)$ & $7.6(4.5-11)^{\mathrm{a}}$ & $7.9(6.7-10.3)^{\mathrm{a}}$ & $7.9(5.6-10.2)^{\mathrm{a}}$ & $7.0(4.4-8.4)^{\mathrm{a}}$ \\
\hline
\end{tabular}

NOTE: Results are expressed as means with ranges in parentheses.

a $p<0.01$ vs normal subjects.

${ }^{b} \times 10^{-3}$. 

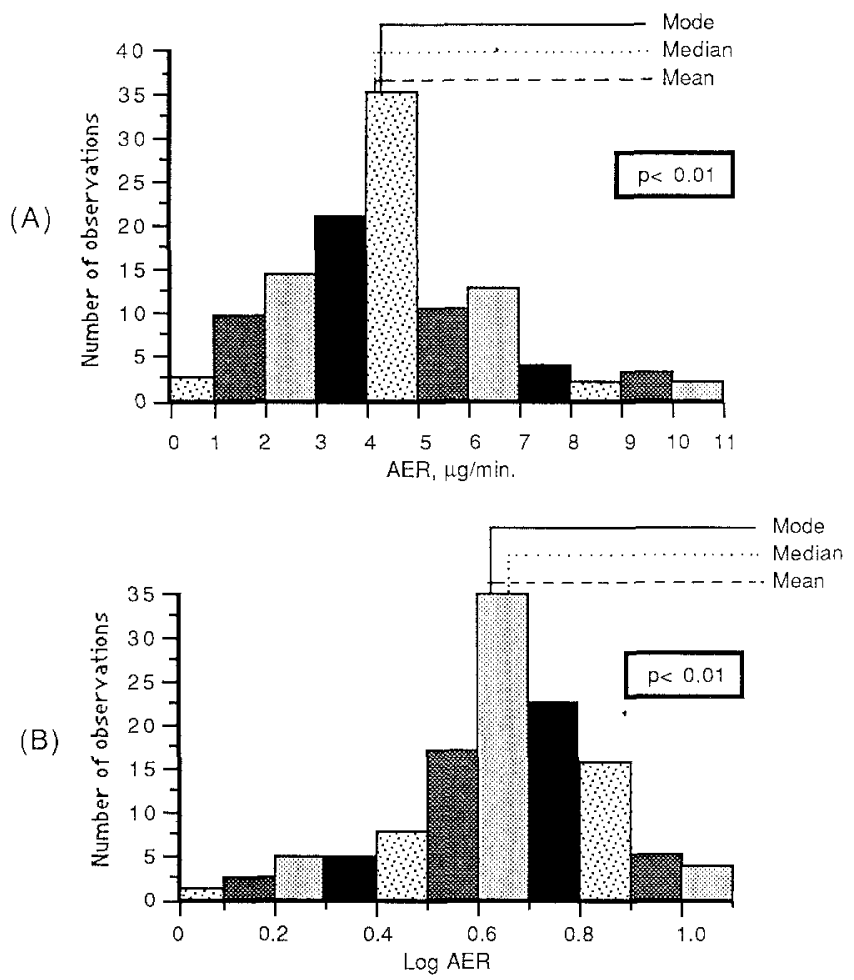

(C)

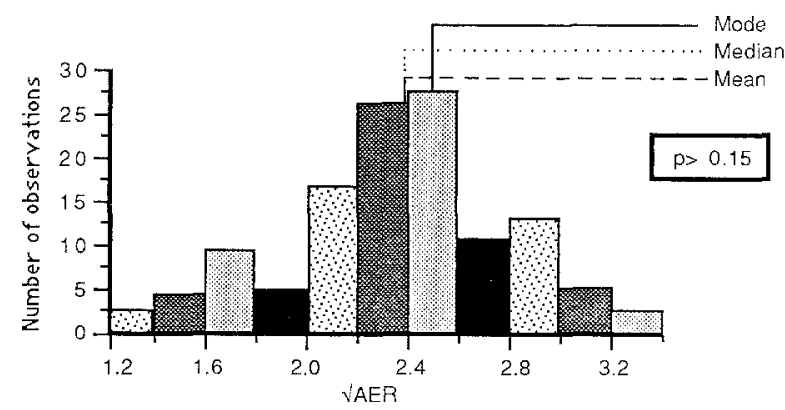

Figure 2-(A) Distribution of AER data in 122 normal subjects, (B) log-transformation, and (C) square-root transformation of values. Only the last distribution was not significantly different from a normal one.

The mean AER of microalbuminuric type I patients (36.9 $\pm 28 \mu \mathrm{g} / \mathrm{min}$; range $15-110$ ) also did not differ significantly from that found in microalbuminuric type II diabetics ( $26 \pm 7.4 \mu \mathrm{g} / \mathrm{min}$; range 18-39) (Table 2).

After the exclusion of the microalbuminuric patients (AER $>15 \mu \mathrm{g} / \mathrm{min} ; n=29$ ), both $\log$ and square-root transformations normalized the AER distribution in diabetic subjects. We found a weak $(r=0.25, p<0.02$; $n=115$ ) correlation between the duration of diabetes and AER in type I diabetic patients but no such relationship between glycated hemoglobin and AER values in these patients.

In normal and in diabetic subjects, the mean coefficient of variation of the AER was about 30\% (range 29$33 \%$ ), and that of urine volumes ranged between 21 and $26 \%$.

\section{Discussion}

The RIA method is rapid, sensitive, acceptably precise, and has a wide linear dynamic range. Urine samples can be preserved without additives, with no loss of immunoreactive urinary albumin concentration, and the assay may be performed on prefrozen urine samples. The best type of urine collection (e.g., $24 \mathrm{~h}$ or overnight collection, morning or random urine samples, forced diuresis) has yet to be decided (13-14,19-21). Day-today and intra-day variation of urinary protein excretion, including albumin, is a well-documented phenomenon (22). In our study, the mean coefficient of variation of the AER (29-33\%) compares favorably with that reported in other studies employing overnight collection $(2,3,13,21,23)$, and in our opinion overnight urine collection is suitable for the measurement of microalbuminuria and we recommend the collection of a mini-

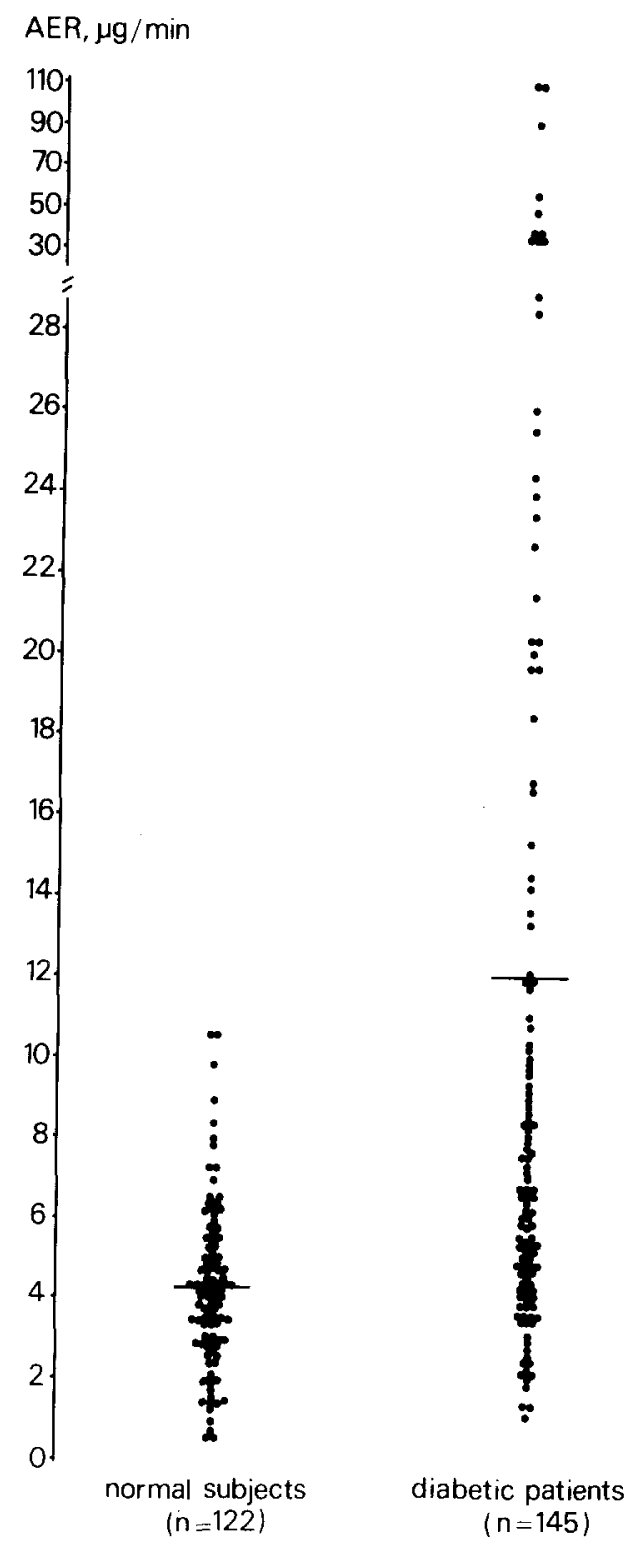

Figure 3-AER values in normal and diabetic subjects. Each bar represents the corresponding mean value.

CLINICAL BIOCHEMISTRY, VOLUME 21, JANUARY 1988 
mum of three consecutive overnight urine samples $(13,14,19,24)$, in order to accurately assess the AER.

AER values obtained in our normal subjects (4.42 \pm $1.99 \mu \mathrm{g} / \mathrm{min}$ ) are similar to those found by others (Mogensen: $4.3 \pm 1.3 \mu \mathrm{g} / \mathrm{min},(1,5)$; Hemmingsen and Skaarup: $4.31 \mu \mathrm{g} / \mathrm{min}$, ref. 22 ), but are lower than those found from others (Viberti et al.: $6.6 \pm 3.2 \mu \mathrm{g} / \mathrm{min}$; (25); Brodows et al.: $6.5 \pm 2.2 \mu \mathrm{g} / \mathrm{min}$, ref. 12 ). These differences confirm how important it is for each laboratory involved in an AER study $(1,5,12,22,25,26)$ to have their own normal range calculated on a proper group of healthy controls. Data from our 122 healthy subjects confirm that the distribution of urinary albumin excretion is not Gaussian (23,24,26-28).

For statistical analysis of albuminuria values, it is advisable to employ nonparametric methods or, alternatively, to try to normalize data by log or square-root (as in our case) transformation.

Diabetics (type I and type II) showed a mean AER significantly higher than normals even after excluding the microalbuminuric subjects (Figure 3 and Table 2), because $27 \%$ of diabetics exceeded the upper normal limit (Figure 3). A weak correlation between the diabetes duration and the AER was found only in type I patients, in accordance with other authors $(26,27,29)$. We observed no correlation between AER and HbA1c in diabetics possibly due to their narrow range of glycated hemoglobin. Most values ranged between 7 to 10\%. In studies showing a correlation between AER and $\mathrm{HbAl}(27,30)$, patients with very high $\mathrm{HbAl}$ levels had been included.

By our RIA, urinary albumin measurement is accurate and sensitive. Hence, the method may be used for transversal and longitudinal studies of diabetic nephropathy (31-35), if urines are collected by a standardized procedure $(27,36,37)$.

\section{Acknowledgements}

We are very grateful to Francesco Caricato for his technical assistance in performing albumin radioimmunoassay and to Mrs. Lia Russo for her excellent accuracy in preparing the manuscript.

This study was supported in part by a grant (84.02442.56) from the National Research Council and by a grant from the Ministero della Pubblica Istruzione (Ricerca Scientifica 1985).

\section{References}

1. Mogensen CE. Microalbuminuria and incipient diabetic nephropathy. Diabetic Nephropathy 1984; 3: 75-8.

2. Viberti GC, Wiseman M, Redmond S. Microalbuminuria: its history and potential for prevention of clinical nephropathy in diabetes mellitus. Diabetic Nephropathy 1984; 3: 79-82.

3. Viberti GC, Jarrett RJ, Mahmud U, Hill RD, Argyropulos A, Keen $\mathrm{H}$. Microalbuminuria as a predictor of clinical nephropathy in insulin-dependent diabetes mellitus. Lancet 1982; 1: 1430-2.

4. Parving HH, Oxenboll B, Svendsen PA, Sandahl Christiansen J, Andersen AR. Early detection of patients at risk of developing diabetic nephropathy. A longitudinal study of urinary albumin excretion. Acta Endocrinol 1982; 100: $550-5$.
5. Mogensen CE, Christensen CK. Predicting diabetic nephropathy in insulin-dependent patients. $N$ Engl J Med 1984; 311: 89-93.

6. Mogensen CE. Microalbuminuria predicts clinical proteinuria and early mortality in maturity-onset diabetes. N Engl J Med 1984; 310: 356-60.

7. Borch-Johnsen K, Andersen PK, Deckert T. The effect of proteinuria on relative mortality in type I (insulindependent) diabetes mellitus. Diabetologia 1985; 28: $590-6$.

8. Mathiesen ER, Oxenboll B, Johansen K, Svendsen PA, Deckert $T$. Incipient nephropathy in type I (insulin-dependent) diabetes. Diabetologia 1984; 26: 406-10.

9. Keen H, Chlouverakis C. An immunoassay method for urinary albumin at low concentrations. Lancet 1963; 2: $913-4$.

10. Miles DW, Mogensen CE, Gundersen HJG. Radioimmunoassay for urinary albumin using a single antibody. Scand J Clin Lab Invest 1970; 26: 5-11.

11. Woo J, Floyd M, Cannon DC, Kahan B. Radioimmunoassay for urinary albumin. Clin Chem 1978; 24: 1464-7.

12. Brodows RG, Nichols D, Shaker G, Kubasik NP. Evaluation of a new radioimmunoassay for urinary albumin. Diabetes Care 1986; 9: 189-93.

13. Mogensen CE. Urinary albumin excretion in early and long-term juvenile diabetes. Scand J Clin Lab Invest 1971; 28: 183-93.

14. Feldt-Rasmussen B, Mathiesen ER. Variability of urinary albumin excretion in incipient diabetic nephropathy. $\mathrm{Di}$ abetic Nephropathy 1984; 3: 101-3.

15. Hunter WM, Greenwood FC. Preparation of iodine-131labelled human growth hormone of high specific activity. Nature 1962; 194: 495-502.

16. Pilo A, Zucchelli GC. Automatic treatment of radioimmunoassay data: an experimental validation of the results. Clin Chim Acta 1975; 64; 1-9.

17. SAS User's Guide: Statistics, Version 5 Edition, Cary, NC (USA), SAS Institute Inc, 1985.

18. Somers RH. A new asymmetric measure of association for ordinal variables. Am Sociolog Rev 1962; 27: 799811.

19. Price DA, Fielding BA, Davies AG, Postlethwaite RJ. Short-term variability of urinary albumin excretion in normal and diabetic children. Diabetic Nephropathy 1985; 4: 169-71.

20. Cowell CT, Rogers S, Silink M. First morning urinary albumin concentration is a good predictor of 24-hour urinary albumin excretion in children with type I (insulindependent) diabetes. Diabetologia 1986; 29: 97-9.

21. Jarrett RJ, Viberti GC. Risk of nephropathy in diabetes mellitus: problems of methodology and terminology. Diabetologia 1985; 28: 181 (Letter).

22. Hemmingsen L, Skaarup P. The 24-hour excretion of plasma proteins in the urine of apparently healthy subjects. Scand J Clin Lab Invest 1975; 35: 347-53.

23. Harmoinen A, Ala-Houhala I, Vuorinen P. Rapid and sensitive immunoassay for albumin determination in urine. Clin Chim Acta 1985; 149: 269-74.

24. Feldt-Rasmussen B, Disesen B, Deckert M. Enzyme immunoassay: an improved method for determination of urinary albumin in diabetics with incipient nephropathy. Scand J Clin Lab Invest 1985; 45: 539-44.

25. Viberti GC, Mackintosh D, Keen H. Determinants of the penetration of proteins through the glomerular barrier in insulin-dependent diabetes mellitus. Diabetes 1983; 32 (Suppl 2): 92-5.

26. Suzuki M, Waldeck N, Vaziri ND, et al. The interrelationships of radioimmuno-assayable urinary albumin, renal 
GIAMPIETRO, MICCOLI, CLERICO, ET AL.

function and diabetes. Diabetes Res Clin Pract 1986; 2: $43-50$.

27. Rowe DJ, Hayward M, Bagga H, Betts P. Effect of glycaemic control and duration of disease on overnight albumin excretion in diabetic children. Br Med $J$ 1984; 289: 957-9.

28. Viberti GC, Pickup JC, Jarrett J, Keen H. Effect of control of blood glucose on urinary excretion of albumin and microglobulin in insulin-dependent diabetes. $N$ Engl $J$ Med 1979; 300: 638-41.

29. Davies AG, Price DA, Postlethwaite R J, Fielding BA. Urine albumin excretion in diabetics. Lancet 1985; 1: 466-7.

30. Viberti GC, Mackintosh D, Bilous RW, Pickup JC, Keen $\mathrm{H}$. Proteinuria in diabetes mellitus: role of spontaneous and experimental variation of glycemia. Kidney Int 1982; 21: $714-20$.

31. Viberti GC, Keen H. The patterns of proteinuria in diabetes mellitus. Relevance to pathogenesis and prevention of diabetic nephropathy. Diabetes 1984; 33: 686-92.
32. Rosenstock J, Raskin P. Early diabetic nephropathy: assessment and potential therapeutic interventions. Diabetes Care 1986; 9: 529-45.

33. Mogensen CE. Microalbuminuria. In: Nattrass M Ed. Recent advances in diabetes. Pp 139-50 Edinburgh: Churchill Livingstone, 1986.

34. Viberti GC, Wiseman MJ. The kidney in diabetes: significance of the early abnormalities. Clin Endocrinol Metab 1986; 15: 753-82.

35. Mogensen CE. Microalbuminuria as a predictor of clinical diabetic nephropathy. Kidney Int 1987; 31: 673-89.

36. Rowe DJF, Bagga $H$, Betts PB. Normal variations in rate of albumin excretion and albumin to creatinine ratios in overnight and daytime urine collections in non-diabetic children. Br Med J 1985; 291: 693-4.

37. Marre M, Claudel JP, Ciret P, Luis N, Suarez L, Passa P. Laser immunonephelometry for routine quantification of urinary albumin excretion. Clin Chem 1987; 33: 209-13. 